\title{
Alternatively Spliced Transcripts of the flp-1 Gene Encode Distinct FMRFamide-like Peptides in Caenorhabditis elegans
}

\author{
Marc L. Rosoff,' Thomas R. Bürglin, ${ }^{2}$ and C. Li' \\ 'Department of Biology, Boston University, Boston, Massachusetts 02215 and ${ }^{2}$ Department of Molecular Biology, \\ Massachusetts General Hospital and Department of Genetics, Harvard Medical School, Boslon, Massachusetts 02114
}

\begin{abstract}
We have isolated and characterized several cDNAs and the corresponding genomic region of a gene encoding multiple FMRFamide-like neuropeptides from the nematode Caenorhabditis elegans. The gene, named flp-1, consists of six exons of which four encode FMRFamide-like peptides. The CDNA and genomic sequences revealed that two distinct transcripts are generated by the use of an alternative $3^{\prime}$ splice acceptor site between exons 3 and 4 . This alternative splice results in the substitution of AGSDPNFLRFG for one of the copies of SADPNFLRFG found in the other translation product. Based on PCR analysis of RNA from mixed-stage animals, both transcripts are expressed. This gene is the first example of a distinct FMRFamide-like peptide being derived from alternative splicing, suggesting a unique role for the substituted peptide in the animal.
\end{abstract}

Although it has been shown that environmental factors can influence transmitter choice (for reviews, see Le Douarin, 1980; Landis, 1983; Potter et al., 1983), little is known about the molecular mechanisms that are involved in the determination of transmitter specificity. To study this problem, we have chosen to investigate the control of neuropeptide gene expression in the nematode Caenorhabditis elegans, which offers several experimental advantages. The complete connectivity diagram of the nervous system has been described (White et al., 1986), the animal is amenable to genetic manipulations (Brenner, 1974), and methods for the construction of transgenic animals are well established in C. elegans (Fire et al., 1990).

We have focused on the neuropeptide Phe-Met-Arg-Phe- $\mathrm{NH}_{2}$ (FMRFamide), which was first discovered as a cardioactive agent in the venus clam Macrocallista nimbosa (Price and Greenberg, 1977). FMRFamide-like immunoreactivity has since been described in a broad range of phyla (for review, see Price and Greenberg, 1989), and purification of the peptides has revealed a large family of FMRFamide-related peptides that share a common C-terminal Arg-Phe- $\mathrm{NH}_{2}$. These peptides have been shown to act as conventional neurotransmitters (Kuhlman et al., 1985;

Received Nov. 6, 1991; revised Jan. 15, 1992; accepted Jan. 16, 1992.

We are greatly indebted to Gary Ruvkun, in whose lab this work was started. We also thank Stuart Kim, Bob Barstead, and Scott Emmons for generously donating their cDNA or genomic libraries; David Price, Tim Geary, and Cindy Cowden for sharing their unpublished results; Thomas Gilmore and Dean Tolan for comments on the manuscript; and members of our lab and the Ruvkun, Brent, and Gilmore labs for their many helpful discussions. This work was supported by NIH Grant HD25212 to C.L.

Correspondence should be addressed to Dr. C. Li, Department of Biology, Boston University, 2 Cummington Street, Boston, MA 02215.

Copyright (C) 1992 Society for Neuroscience $0270-6474 / 92 / 122356-06 \$ 05.00 / 0$
Li and Calabrese, 1987; Norris and Calabrese, 1987) as well as neuromodulators (for review, see Raffa, 1988). In addition, recent work has shown that FMRFamide can regulate the number of presynaptic varicosities in sensory cells of Aplysia (Schacher and Montarolo, 1991).

Genes encoding FMRFamide-like peptides have been isolated from a variety of organisms. The putative prohormone or precursor protein encoded by these genes consistently contains multiple distinct FMRFamide-like peptides, some of which may be present in multiple copies and all of which are flanked by potential proteolytic cleavage sites. For instance, the Aplysia gene encodes 28 copies of FMRFamide and 1 copy of the related peptide Phe-Leu-Arg-Phe- $\mathrm{NH}_{2}$ (FLRFamide) (Taussig and Scheller, 1986). By contrast, the Drosophila gene encodes peptides that are all N-terminal extensions of FMRFamide or the related peptide Phe-Ile-Arg-Phe- $\mathrm{NH}_{2}$ (FIRFamide), and no copies of the tetrapeptides FMRFamide or FIRFamide (Nambu et al., 1988; Schneider and Taghert, 1988). The precursor protein of Lymnaea stagnalis contains the tetrapeptides FMRFamide and FLRFamide as well as peptides with $\mathrm{N}$-terminal extensions of FLRFamide (Linacre et al., 1990; Saunders et al., 1991).

In the adult hermaphrodite of $C$. elegans, approximately $10 \%$ or 30 neurons stain with an antibody that is specific for the ArgPhe- $\mathrm{NH}_{2}$ portion of FMRFamide (Schinkmann and Li, 1992). The immunoreactive cells include motor, sensory, and interneurons, and several are components of the egg-laying and defecation systems. In addition, FLRFamide appears to be modulatory in an egg-laying assay (Schinkmann and Li, 1992).

In this article, we report the cloning and genomic organization of a gene, $f l p-1$ (FMRFamide-like peptide), which encodes multiple FLRFamide-containing peptides in C. elegans. As a result of alternative splicing, two distinct transcripts are generated. One transcript codes for a precursor protein that contains seven different peptides; the second transcript codes for a precursor protein that contains eight distinct peptides. Thus, the $f l p-1$ gene generates neuropeptide diversity in two ways: by encoding multiple neuropeptides and by alternative splicing.

\section{Materials and Methods}

Growth and maintenance of bacterial strains. Growth and maintenance of bacterial strains and $\lambda$-phage were carried out according to Sambrook et al. (1989).

Cloning and sequencing of $c D N A$ s and the genomic fragment corresponding to flp-1. Standard molecular biological techniques were performed according to Sambrook et al. (1989).

Oligonucleotides coding for FMRFGK/R that were 64-fold $\left(5^{\prime}\right.$ XCGXCCRAAYCTCATRAA-3'; 5'-YYTXCCRAAYCTCATRAA-3') and 128-fold (5'-XCGXCCRAAXCGCATRAA-3'; 5'-YYTXCCRAAXCGCATRAA-3') degenerate were used to screen a $\lambda \mathrm{gt} 10$ cDNA 
library (Kim and Horvitz, 1990), using a modification of the method of Bürglin et al. (1989). Hybridization was performed at $35^{\circ} \mathrm{C}$, and washes were done at $42.5^{\circ} \mathrm{C}$ in $3 \mathrm{M}$ tetramethylammonium chloride, 0.2 mM EDTA, and $50 \mathrm{~mm}$ Tris ( $\mathrm{pH}$ 8.0). cDNAs were subcloned into pBS + (Stratagene). Double-stranded sequencing was performed according to a modified version of the dideoxy protocol of Sanger et al. (1977), using Sequenase version 2.0 (United States Biochemical) and oligonucleotide primers.

A $\lambda$ Zap cDNA library (Barstead and Waterston, 1989) was probed with clone 3-3W, and screened using the following procedure. The filters were prehybridized in $6 \times \operatorname{SSPE}\left(0.9 \mathrm{M} \mathrm{NaCl}, 60 \mathrm{mM} \mathrm{NaH}_{2} \mathrm{PO}_{4} \cdot \mathrm{H}_{2} \mathrm{O}\right.$, and $6 \mathrm{~mm}$ EDTA), $5 \times$ Denhardt's solution, $1 \%$ SDS with $2 \mu \mathrm{g}$ of denatured yeast tRNA at $65^{\circ} \mathrm{C}$ for $1 \mathrm{hr}$. Hybridization was carried out using $100 \mathrm{ng}$ of random primer labeled clone $3-3 \mathrm{~W}$ insert at $65^{\circ} \mathrm{C}$ overnight. The filters were washed $2 \times$ for $1 \mathrm{hr}$ at $65^{\circ} \mathrm{C}$ in $1 \times$ SSPF and $0.1 \%$ SDS. After two rounds of purification, positive clones were excised into pBluescript according to the manufacturer's protocols and sequenced as above.

A $\lambda 1059$ genomic library (kindly donated by Scott Emmons, Albert Einstein College of Medicine) was screened using clone 3-3W as a probe and the protocol described above. A unique 3 kilobase (kb) hybridizing EcoRI fragment was subcloned into $\mathrm{pBS}+$ and sequenced as above.

$R N A$ isolation and primer extension analysis. C. elegans were grown in liquid culture and isolated according to Wood (1988). Mixed stage animals were concentrated in M9 salts (Wood, 1988). RNA extraction was performed on fresh animals using the procedure of Chomczynski and Sacchi (1987) with the following modifications. In microcentrifuge tubes, $500 \mu \mathrm{l}$ of concentrated worms were combined with $500 \mu \mathrm{l}$ of a modified solution D (4 M guanidinium thiocyanate, $25 \mathrm{~mm}$ sodium citrate, $0.5 \%$ sarcosyl, and $0.1 \mathrm{~m} 2$-mercaptoethanol). After the final precipitation, RNA was resuspended in water and extracted $5 \times$ with phenol/chloroform. The RNA was then precipitated $2 \times$ in ethanol and resuspended in water.

Primer extension analysis was carried out according to the method of Boorstein and Craig (1989), using $50 \mu \mathrm{g}$ of total RNA and 1 pmol of end-labeled oligonucleotide primer $33 \mathrm{wp} 8\left(5^{\prime}\right.$-TGCTCCATGGTGGAGAGC- $3^{\prime}$ ). Extension products were analyzed on a $6 \%$ polyacrylamide, $7 \mathrm{M}$ urea denaturing sequencing gel. Products were visualized by autoradiography with intensifying screens after a 1 week exposure.

Reverse transcription $/ P C R$. Samples of total RNA $(30 \mu \mathrm{g})$ were precipitated in 2 volumes of ethanol using sodium acetate and resuspended in $3.6 \mu \mathrm{l}$ water. To each RNA sample, the following was added: $\mathrm{MgCl}_{2}$ (final concentration, $3.5 \mathrm{~mm}$ ), dNTPs ( $1 \mathrm{~mm}$ final concentration of each), $50 \mathrm{pmol}$ of $3^{\prime}$ primer (33wP2: 5'-GGATTCACGATCGAAG-3'), 38U RNAsin (Promega), $2 \mu$ l of $10 \times$ PCR buffer (Tris $\mathrm{HCl}, \mathrm{pH} 8.3,100$ $\mathrm{mm} ; \mathrm{KCl}, 500 \mathrm{~mm}$; gelatin, $0.01 \%$ ), and $8 \mathrm{U}$ of avian myoblastosis virus (AMV) reverse transcriptase (Promega). Each reaction was carried out in a total volume of $20 \mu \mathrm{l}$ at $42^{\circ} \mathrm{C}$ for $1 \mathrm{hr}$.

To the cDNA synthesis reactions $100 \mathrm{pmol}$ of $5^{\prime}$ primer (MR3 5'TGCTCTACCAAGTAGGGT-3') and 100 pmol of $3^{\prime}$ primer (33wP2) were added. The volume was brought to $50 \mu \mathrm{l}$ with $\mathrm{dH}_{2} \mathrm{O}$. Two positive control reactions, using $7 \mathrm{ng}$ of a plasmid clone of transcript $\mathrm{A}$ and 7 ng of a plasmid clone of transcript $B$, were set up using the same concentrations of deoxynucleotides, salts, and buffers as in the cDNA synthesis above, but without RNAsin and AMV reverse transcriptase. A negative control without template DNA was set up similarly to the positive controls. The reaction tubes were denatured at $94^{\circ} \mathrm{C}$ for $5 \mathrm{~min}$ and centrifuged briefly, and $8 \mu \mathrm{l}$ of $10 \times$ PCR buffer, $1.6 \mu \mathrm{l}$ of $50 \mathrm{~mm}$ $\mathrm{MgCl}_{2}, 40 \mu \mathrm{l}$ of $\mathrm{dH}_{2} \mathrm{O}$, and $2.5 \mathrm{U}$ of Taq polymerase (Cetus) were added; mincral oil was placed on top, and the tubcs werc placed in a PcrkinElmer DNA thermocycler. Amplification was carried out for 5 cycles of $94^{\circ} \mathrm{C} 1 \mathrm{~min}, 37^{\circ} \mathrm{C} 1.5 \mathrm{~min}, 72^{\circ} \mathrm{C} 1 \mathrm{~min}$ followed by 30 cycles $94^{\circ} \mathrm{C}$ $1 \mathrm{~min}, 42^{\circ} \mathrm{C} 1 \mathrm{~min}, 72^{\circ} \mathrm{C} 3 \mathrm{~min}$.

One half of each PCR reaction was electrophoresed on an agarose gel containing $0.5 \%$ Nusieve agarose and $1 \%$ agarose. This was then blotted onto GeneScreen (New England Nuclear) and probed with random primer labeled clone 3-3W insert as described for genomic restriction mapping (data not shown). An aliquot of the other half of the reactions was run on a $6 \%$ polyacrylamide gel and visualized by staining with ethidium bromide.

\section{Results}

Cloning of CDNAS

Two sets of 64- and 128-fold degenerate oligonucleotides coding for FMRFG $(\mathrm{R} / \mathrm{K})$ were used to screen a mixed-stage $\lambda \mathrm{gt} 10 \mathrm{cDNA}$ library (Kim and Horvitz, 1990). From approximately 400,000 plaques, 16 hybridizing clones were isolated and grouped into four classes by their cross-hybridization patterns. DNA sequence analysis showed that clones from only one class encoded multiple FMRFamide-like peptides. The four clones in this class were sequenced and were found to be essentially identical. The longest clone, clone $3-3 \mathrm{~W}$, is 659 base pairs (bp) long, has a single, long open reading frame encoding 163 amino acids, and contains a polyA tail 14 bp long (Fig. 1).

Clone $3-3 \mathrm{~W}$ was used to probe a second mixed-stage $\lambda \mathrm{Zap}$ cDNA library (Barstead and Waterston, 1989). Approximately 130,000 plaques were screened, and four hybridizing clones were isolated. These clones were sequenced, and comparison of the sequences revealed that the clones fell into two distinct classes. Two clones had 33 extra nucleotides in the region corresponding to position 238 in clone $3-3 \mathrm{~W}$. The other two lacked this insertion and were essentially identical to clone 3-3W. Hereafter, the transcript represented by clone $3-3 \mathrm{~W}$ will be referred to as transcript $A$, and the transcript with the $33 \mathrm{bp}$ insertion as transcript $\mathrm{B}$.

\section{Genomic organization of the flp-1 gene}

To isolate genomic sequences corresponding to the cDNAs, we probed approximately 300,000 plaques from a $\lambda 1059$ genomic library with clone $3-3 \mathrm{~W}$. Thirteen hybridizing clones were isolated, and separated into four classes by restriction mapping. One clone from each class was mapped further (Fig 2). A unique hybridizing EcoRI fragment, $3 \mathrm{~kb}$ in length, was subcloned and sequenced on both strands (Fig. 1). The genomic organization of $f l p-1$ is shown in Figure 2 . The $f l p-1$ gene contains six exons. As a result of intron 3 , the coding region for the second putative peptide in both transcripts is split among exons 3 and 4 (Figs. 1,2). This division of the coding region of peptide 2 represents a unique organization not found in any of the other genes coding for FMRFamide-like peptides. Three of the introns are relatively short $(\leq 85 \mathrm{bp})$, one is of medium length (156 bp), and one is fairly large (434 bp). The neuropeptide-coding region spans from the end of exon 3 to roughly half of exon 6 (Figs. $1,2)$. There is an imperfect polyadenylation signal, AATGAAA, $18 \mathrm{bp}$ upstream of the start of polyadenylation in all six cDNAs with a polyA tail. No other polyadenylation signal was found in the sequence 500 bp downstream of the stop codon.

\section{Transcripts $A$ and $B$ result from alternative splicing}

Comparison of the genomic and cDNA sequences indicated that the two transcripts were a result of alternative splicing. Transcript $B$ results from the use of a different $3^{\prime}$ splice acceptor site in the joining of exons 3 and 4 than transcript $A$ (Fig. 1), resulting in a translation product 11 amino acids longer than the translation product of transcript A (see Fig. 5). Both $3^{\prime}$ splice acceptors show approximately the same agreement with the C. elegans consensus sequence (Wood, 1988).

\section{Primer extension analysis}

To determine whether the isolated cDNAs were full length, primer extension experiments were performed using primer $33 \mathrm{wp} 8$, which was positioned 99 nucleotides downstream from the $5^{\prime}$ end of clone 3-3W. Extensions were performed at both $42^{\circ} \mathrm{C}$ and $52^{\circ} \mathrm{C}$ (Fig. 3). Two bands, corresponding to transcripts that are 11 and 12 nucleotides longer than clone $3-3 \mathrm{~W}$, were seen when the extension was performed at $42^{\circ} \mathrm{C}$. Only one band, corresponding to a transcript 11 nucleotides longer than clone 
T* Met ThrLeuLeuTyrGinValglyLeuLeuLeuLeuValalaAlaThrTyrLys

TGTTGCACACCGGGAGCCACTTCAGACTTTTGTACGGTCTTCTCGATGCTCTCCACCATGGAGCAAAATGAAGTGATGAACTTTATAGGTTTGTTCCTTTTGATTTCATTGAAGGGTTTA 240 CysCysThrProGlyAlaThrSerAspPheCysThrValPheSerMetLeuSerThrMetGluglnAsnG uvalMetAsnPheIleG

GTATACTATTCATTTAAAAAATATTGCCTACAATTGATAAGGTTATTTAGATAATGATTTAAAAAACTTCCAAATACGGGGAAAATCATGGTTATAACATTTAATTAGATTGATTTCAAA

ATTTAACT TAAGATCAACTGAAAACATATTCTAACTCTATAATTAGGGTCTT'I'G'I'I'AGA'I'A'I"I'I'GG'ICG'I'I'AGAAAACCCGC'IAI'G'I'AAT'CACAAAAAGGCCTGTCTCGCCTGCCTCATG

CCTGCACGGGTGTTCGTTGAACCTTGTGCGTAAATCAAGACTTTGCGCCTAAATGTACAAAATAAGAGATAGGCGGGCAGGCATAAGGCATGCAAGCTCGTCTGAAGCAACGCCTTCCTG

CCAAGGTATCTGATGAATTTTCATAATATTTCCTCATTTTCAGGTGAAAACTGCGATGGTGATGCCGAGGTGGCACTGCAAAAGATGGAAAAGAGAAAGCCAAACTTTATGAGATATGGG lyGluAsnCysAspGIYAspAlaGluValAlaLeUGInLysMetGl ULysArgLysP rOAsnPheMetArgTyrGly

CGATCAGCAGGTAAGTCTAACCTTTTTCTGATAAAAAAGAGCACAACTTGGTGCTCTTTTAGCTGTAAAGTCGCTGGGAAAGAAAGCCGGTTCAGACCCGAACTTCCTTCGATTCGGACG ArgSerAlaA

ATCTCAACCAAACTTCTTGCGATTCGGAAAGGCTAGCGGAGACCCGAACTTCCTTCGTTTCGGTGAGTATTTGAATGGATTGGATTTGAAGAACATTTCAGATCTAACGATTCGAACTAA GSerGlnP rOAsnPheLeuArgPheGlyLysAlaSerGlyAspP roAsnPheLeuArgPheG

ATTTCAGTTTATTTGCAAACAAAGCTTCCTCTCATAAAGATAGTCAGTTAGGGAACAAAATAGAAAATAATCAAGATTCTAAATGATAATCATTTTCAGGTCGAAGTGACCCTAACTTCT

TGAGATTTGGAAAAGCCGCTGCTGATCCAAATTTCTTGAGATTCGGAAAACGATCTGCAGATCCTAACTTCTTGAGGTATGTTAAAAACAAAAATTATAATATTATCAAATTATTTCTTC euArgPheGlyLysAlaAlaAlaAsp? roAsnPhe LeuArgPheGlyLysArgSerAlaAspP roAsnPheLeuAr

AGA'I'I'CGGACGC'I'CA'I"I'CGACAAC'I'TCGATCGTGAATCCCGCAAGCCAAATTTCCTTCGTTTCGGAAAATAAGAAACTAAAACTTCGACCGTCAGCATCAGATCGATCACACTCACACAG gPheGl yArgSerPheAspAsn PheAspArgGl uSerArgLy SP roAsnPhe LeuArgPheGly Ly sEnd

CAGCTAATTCAGGAACAATTTCTCTATTTTCTCTATTCTCTTITCGTCTTTTTATCTTICAGTGTCATTTGTTTTTGAAAATGAAAGAAATATTTTGAAATTTT 1424

Figure 1. Sequence of genomic region and cDNAs of $f l p-1$. Sequence of genomic region containing the $f l p-1$ gene is shown with the translation products deduced from the cDNAs below. Amino acids found exclusively in transcript B are boxed. A potential TATAAT box is underlined (thick line). Start site of transcription, as determined by primer extension, is denoted by an arrow. The $5^{\prime}$ end of the longest cDNA (clone 3-3W) is indicated by an asterisk. The hydrophobic region that may serve as a signal sequence is underlined (thin line) and a potential signal sequence cleavage site is indicated (arrowhead). The polyadenylation signal is underlined (dashed line). Numbering of amino acids is shown for translation product $\mathrm{A} /$ translation product $\mathrm{B}$.

3-3W, was seen when the reaction was performed at $52^{\circ} \mathrm{C}$. No bands were detected in the control reaction using yeast tRNA. This experiment has been repeated using varying amounts of total RNA at $42^{\circ} \mathrm{C}$ and has given identical results. From these results, we conclude that the start site of transcription is $12 \mathrm{bp}$ upstream of the $5^{\prime}$ end of our longest cDNA, clone 3-3W.

Examination of the genomic sequence immediately upstream of the cDNA revealed a possible initiator methionine (Fig. 1).
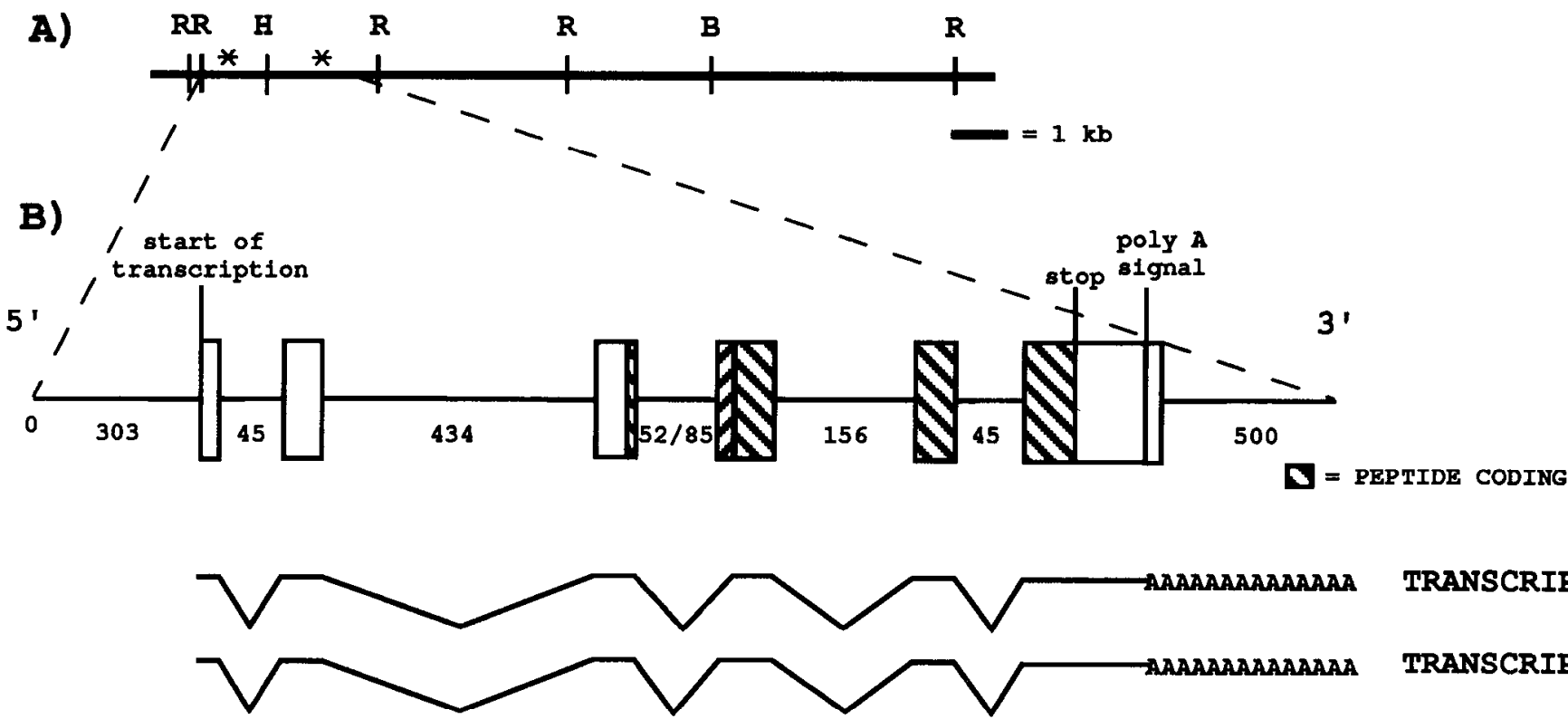

TRANSCRIPT A TRANSCRIPT B

Figure 2. A, Restriction map of genomic region containing flp-1. Fragments that hybridize to cDNAs are indicated by asterisks. $B$, BamHI; $H$, HindIII; $R$, EcoRI. $B$, The genomic organization of $f l p-1$, as expanded from $A$. The length of introns in base pairs is indicated below the line. The structures of the transcripts are shown below. 


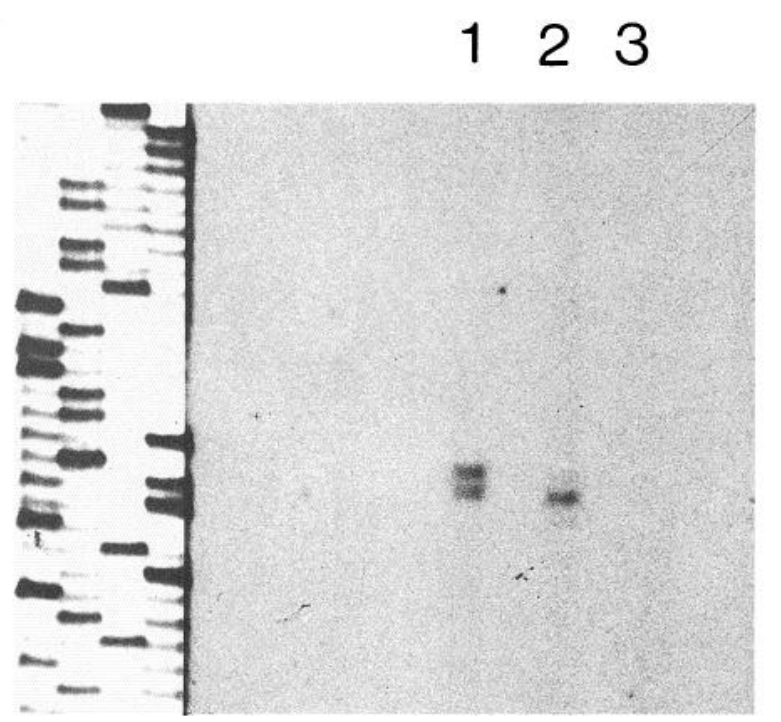

Figure 3. Primer extension analysis to determine the start of transcription. Primer extension products were electrophoresed through a $6 \%$ denaturing acrylamide gel and visualized by autoradiography. Lane 1 , reaction performed at $42^{\circ} \mathrm{C}$; lane 2 , reaction performed at $52^{\circ} \mathrm{C}$; lane 3 , negative control reaction using $50 \mu \mathrm{g}$ of yeast tRNA performed at $42^{\circ} \mathrm{C}$. A sequencing ladder of a $f l p-1$ genomic clone is shown (GATC from left to right). All reactions were performed using $33 \mathrm{wp} 8$ as a primer (see Materials and Methods for experimental details).

This methionine is located $9 \mathrm{bp}$ downstream from the start of transcription and is followed by a region coding for a hydrophobic stretch of amino acids and a potential signal sequence cleavage site (Von Heijne, 1983). Transcripts A and B therefore encode 164 and 175 amino acid precursor proteins, respectively.

\section{Both transcripts appear to be present in C. elegans}

To confirm the presence of both transcripts in the animal, total RNA was isolated from mixed stage animals and reverse transcription/PCR analysis was performed. The amplification products appeared to be present in about equal amounts, as determined by ethidium staining (Fig. 4). Furthermore, as the number of cDNAs isolated for each transcript was approximately the same, these data suggest that the transcripts may arise from comparably expressed mRNAs in the animal.

\section{Putative translation products}

The putative translation products of transcripts A and B contain overlapping sets of FMRFamide-like peptides (Fig. 5). Transcripts A and B code for precursor proteins that contain seven or eight distinct putative peptides, respectively; all of the putative peptides coded for in transcript $\mathrm{A}$ are also coded for in transcript B. Each putative peptide is flanked by either mono-, di-, or tribasic amino acids that are potential cleavage sites (for review, see Loh et al., 1984). Preceding the potential C-terminal cleavage site of each putative peptide is a glycine residue that can potentially donate an amide moiety in the processed peptide (Bradbury et al., 1982).

The first putative peptide contained in both precursor proteins has the sequence PNFMRYG. The remaining seven putative peptides in both precursor proteins are $\mathrm{N}$-terminal extensions of FLRFamide. All of these peptides share a common C-terminal sequence PNFLRFG; in addition, five of these peptides share the sequence DPNFLRFG. In transcript A, one of the

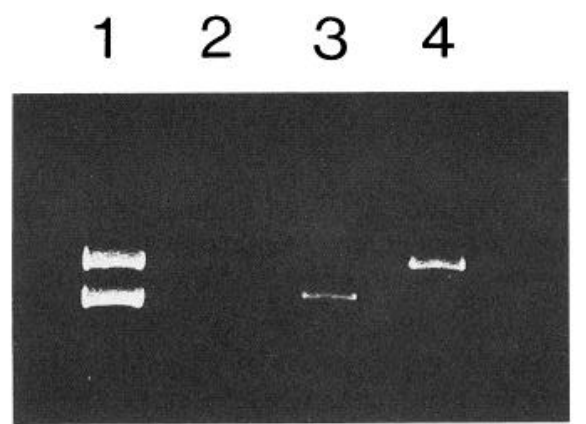

Figure 4. Reverse transcription/PCR analysis to determine presence of both transcripts. Reaction products were electrophoresed through a native $6 \%$ polyacrylamide gel and visualized by staining with ethidium bromide. Lane 1, $30 \mu \mathrm{g}$ of total RNA from mixed stage animals; lane 2 , negative control reaction without template; lane 3, positive control reaction using $7 \mathrm{ng}$ of a transcript A clone; lane 4, positive control reaction using $7 \mathrm{ng}$ of a transcript $\mathrm{B}$ clone (see Materials and Methods for experimental details).

peptides, SADPNFLRFG, is coded for twice while the remaining six are coded for once. The eight putative peptides in transcript B are each represented only once.

Due to the $33 \mathrm{bp}$ insertion in transcript $\mathrm{B}$, a few amino acids at the N-terminal of SADPNFLRFG in translation product A are substituted to yield AGSDPNFLRFG in translation product B. In addition, the translation product of transcript $B$ has an eight amino acid spacer (excluding the potential cleavage site) between the first putative peptide coded (PNFMRYG) and the putative peptide AGSDPNFLRFG. The first seven peptides in the translation product of transcript $A$ and peptides $2-6$ in the translation product of transcript $\mathrm{B}$ have no spacer region between them in the precursor protein. A nine amino acid spacer is found between peptides 7 and 8 in both precursor proteins.

\section{Discussion}

We have isolated and characterized cDNAs corresponding to two distinct transcripts that code for multiple FLRFamide-like peptides from $C$. elegans, the most primitive organism from which a gene encoding FMRFamide-like peptides has been cloned thus far. The corresponding gene, $f l p-1$, produces two transcripts encoding overlapping sets of peptides by use of alternative splicing, similar to the mechanism used for the Aplysia R15 gene (Buck et al., 1987; Weiss et al., 1989). Two of the putative peptides, SDPNFLRF-NH ${ }_{2}$ and SADPNFLRF-NH ${ }_{2}$, have been isolated from the closely related nematode Panagrellus (Geary et al., 1992), which suggests that the same peptides are also produced in $C$. elegans.

\section{Organization of the flp-1 transcripts}

Sequence and primer extension analyses indicate that the $5^{\prime}$ nontranslated region of the $f l p-1$ transcripts is only eight bases. Short $5^{\prime}$ nontranslated sequences of 8,8 , and 15 bases have also been described for the vitellogenin genes vit-4 and vit-5 of $C$. elegans (Spieth et al., 1985) and the segment polarity gene oskar in Drosophila (Ephrussi et al., 1991; Kim-Ha et al., 1991), respectively. Furthermore, the start sites of transcription for vit4 , vit-5, oskar, and $f l p-1$ all appear to occur at the adenine residue of the sequence TCACT, which may represent some form of consensus sequence for the start site of transcription. Another similarity between the vitellogenin genes and $f l p-1$ is the presence of TATAAT boxes whose $5^{\prime}$ ends are at -31 and -33 bp 
A)

TRANSLATION PRODUCT A

MTLLYQVGLLLLVAATYKVSAECCTPGATSDFC

TVFSMLSTMEQNEVMNFIGENCDGDAEVALQKME

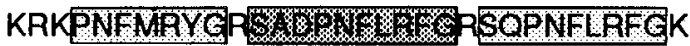

ASGDPNFLRF GRSDPNFLFFGKAAADPNFLREGK

RSADPNFLFFETRSFNFDRESRKPNFLRFGK
B)

\section{TRANSLATION PRODUCT B}

MTLLYQVGLLLLVAATYKVSAECCTPGATSDFC

TVFSMLSTMEQNEVMNFIGENCDGDAEVALQKME

KRKPNFVAYGRSAAVKSLGKK

ASGDPNFLRFG SDPNFLRFGKAAADPNFLRFG $K$

RSADPNFLREGRSDNFDRESRKPNELRFGK

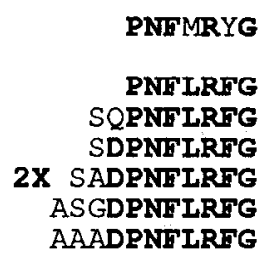

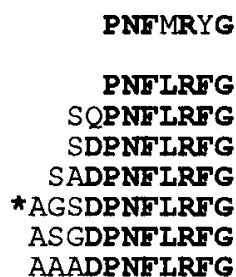

Figure 5. Putative translation products of transcripts A and B are shown with RF-amide peptides in boxes. Each peptide is flanked by either mono-, di-, or tribasic residues that are potential cleavage sites. Peptides in common between the two translation products are in lightly shaded boxes; the peptide that differs between the two transcripts is indicated in the darker shaded boxes (see Results).

relative to the start site of transcription in vit-4 and $f l p-1$, respectively.

Comparison of the structures of the genomic region and translation products for flp-1 with other

FMRFamide-like peptide genes

The genomic organization of $f l p-1$, with six exons, differs from that of genes encoding FMRFamide-like peptides in other organisms. The Drosophila (Chin et al., 1990; Schneider and Taghert, 1990) and Lymnaea (Saunders et al., 1991) genes are split into two exons, while the Aplysia gene has at least two exons (Taussig and Scheller, 1986).

No spacer region is present between most of the putative peptides in the precursor protein encoded by $f p-1$. The spacer regions between the first and second putative peptides in the precursor protein of transcript $B$ and between the seventh and eignth putative peptides in the precursor proteins of both transcripts $A$ and $B$ are not highly acidic and may represent peptides of unknown classes. The Drosophila gene (Nambu et al., 1988; Schneider and Taghert, 1988), one exon encoding GDPFLRFamide and SDPFLRFamide in the Lymnaea gene (Saunders et al., 1991) and the H4 clone from Helix, which codes for N-terminal extensions of FLRFamide (Lutz et al., 1990), show a similar organization. By contrast, spacer regions separate the FMRFamide-like peptides in the Aplysia (Schaefer et al., 1985) gene, clone HF1 from Helix (Lutz et al., 1990), and an exon in the Lymnaea gene (Linacre et al., 1990). The distribution of spacer regions may indicate some pattern relevant to the evolution of these genes.

\section{Peptides coded for in flp-1 may function as hormones}

Peptides of the FMRFamide and FLRFamide classes show marked differences in biological stability. FMRFamide-containing peptides, in contrast to FLRFamide-containing peptides, can undergo oxidation at the methionine residue, resulting in a dramatic decrease in biological activity (Price, 1986). N-terminal extensions of FMRFamide may confer some protection against enzymatic degradation (Price, 1986). The peptides encoded by $f l p-l$ therefore may function as hormones since they lack the methionine residue and have N-terminal extensions. In support of such a role in C. elegans, FLRFamide appears to potentiate the response to 5-HT in an egg-laying assay, and FMRFamide-like immunoreactivity is present in putative neurosecretory cells in the gonad (Schinkmann and $\mathrm{Li}, 1992)$. Other $\mathrm{N}$-terminal extensions of FLRFamide have been localized to neurosecretory cells of the lobster (Trimmer et al., 1987) and pond snail (Brussaard et al., 1988), where the peptides presumably function as hormones.

Does $\mathrm{C}$. elegans contain another gene coding for $R F$-amide peptides?

The $f l p-1$ gene is unusual among the other FMRFamide genes in that it codes for no peptides of the methionine-containing (i.e., FMRFamide) class. Preliminary HPLC analysis of acetone extracts of animals shows a peak that coelutes with authentic FMRFamide (M. L. Rosoff and C. Li, unpublished observations). Furthermore, using an acid-methanol extraction procedure, up to 13 peaks of immunoreactivity were detected by HPLC (C. Cowden, personnal communication). A distinct gene encoding methionine-containing peptides therefore may also be present in $C$. elegans. However, only a single $3 \mathrm{~kb}$ EcoRI fragment hybridizes either to the degenerate oligonucleotides coding for FMRFamide or with the cDNA corresponding to transcript A on Southern blots of genomic DNA (Rosoff and Li, unpublished observations). We are currently isolating FMRFamidelike immunoreactive peptides for amino acid sequencing, and are determining whether the $f l p-1$ expression pattern correlates with the FMRFamide-like immunoreactive staining pattern in C. elegans.

Possible significance of $\mathrm{flp}-1$ coding for multiple FLRFamide-like peptides

Alternative splicing of the $f l p-1$ transcript may be used to generate peptide diversity, as has been shown for the R 15 transcript 
in Aplysia (Buck et al., 1987; Weiss et al., 1989). Determination of the spatial and/or temporal distribution of the two different transcripts of $f l p-l$ and of the different putative peptides may provide insight into the general problem of cell-specific neurotransmitter expression. Clearly, the potential for differential posttranslational processing of the $f l p$ - 1 -encoded precursor protein exists. Such differential processing could result in different subsets of FMRFamide-like peptides being expressed in different neurons in $C$. elegans.

Determining the role of AGSDPNFLRF-NH ${ }_{2}$, the putative peptide resulting from the use of alternative splicing, in the animal's behavior is of particular interest. The use of alternative transcripts may be sex or cell specific, such that the expression of AGSDPNFLRF-NH $\mathrm{N}_{2}$ produces a different physiological response when released in combination with the other peptides. Alternatively, the presence of this peptide in the precursor protein may affect the normal posttranslational processing events, resulting in the production of a different combination of mature peptides.

\section{References}

Barstead RJ, Waterston RH (1989) The basal component of the nematode dense-body is vincullin. J Biol Chem 264:10177-10185.

Boorstein WR, Craig EA (1989) Primer extension analysis of RNA. Methods Enzymol 180:347-369.

Bradbury AF, Finnie MDA, Smyth DG (1982) Mechanism of C-terminal amide formation by pituitary enzymes. Nature 298:686688.

Brenner S (1974) The genetics of Caenorhabditis elegans. Genetics 77: 71-94.

Brussaard AB, Kits KS, Ter Maat A, Van Minnen J, Moed PJ (1988) Dual inhibitory action of FMRFamide on neurosecretory cells controlling egg laying behavior in the pond snail. Brain Res 447:35-51.

Buck LB, Bigelow JM, Axel R (1987) Alternative splicing in individual Aplysia neurons generates neuropeptide diversity. Cell 51:127-133.

Bürglin TR, Finney M, Coulson A, Ruvkun G (1989) Caenorhabditis elegans has scores of homoeobox-containing genes. Nature 341:239243.

Chin AC, Reynolds ER, Scheller RH (1990) Organization and expression of the Drosophila FMRFamide-related prohormone gene. DNA Cell Biol 9:263-271.

Chomczynski P, Sacchi N (1987) Single-step method of RNA isolation by acid guanidinium thiocyanate-phenol-chloroform extraction. Anal Biochem 162:156-159.

Ephrussi A, Dickinson LK, Lehmann R (1991) oskar organizes the germ plasm and directs localization of the posterior determinant $n a$ nos. Cell 66:37-50.

Fire A, White S, Dixon D (1990) A modular set of lacZ fusion vectors for studying gene expression in Caenorhabditis elegans. Gene 93:189198.

Geary TG, Price DA, Bowman JW, Winterrowd CA, Mackenzie CD, Garrison RD, Willians JF, Friedman AR (1992) Two FMRFamidelike peptides from the free-living nematode Panagrellus redivivus. Peptides, in press.

Kim SM, Horvitz RH (1990) The Caenorhabditis elegans gene lin-10 is broadly expressed while required specifically for the determination of vulval cell fates. Genes Dev 4:357-371.

Kim-Ha J, Smith JL, Macdonald PM (1991) oskar mRNA is localized to the posterior pole of the Drosophila oocyte. Cell 66:23-35.

Kuhlman IR, Li C, Calabrese RL (1985) FMRFamide-like substances in the leech. II. Bioactivity on the heartbeat system. J Neurosci 5: 2310-2317.

Landis SC (1983) Development of cholinergic sympathetic neurons: evidence for transmitter plasticity in vivo. Fed Proc 42:1633-1638.

Le Douarin NM (1980) The ontogeny of the neural crest in avian embryo chimaeras. Nature 286:663-669.

Li C, Calabrese RL (1987) FMRFamide-like substances in the leech. III. Biochemical characterization and physiological effects. J Neurosci $7: 595-603$.

Linacre A, Kellet E, Saunders S, Bright K, Benjamin PR, Burke JF
(1990) Cardioactive neuropeptide Phe-Met-Arg-Phe-NH (FMRFamide) and novel related peptides are encoded in multiple copies by a single gene in the snail Lymnaea stagnalis. J Neurosci 10:412-419.

Loh YP, Brownstein MJ, Gainer H (1984) Proteolysis in neuropeptide processing and other neural functions. Annu Rev Neurosci 7:189222.

Lutz EM, Lesser W, Macdonald M, Sommerville J (1990) Novel neuropeptides revealed by cDNAs cloned from Helix aspera. Soc Neurosci Abstr 16:549.

Nambu JR, Murphy-Erdosh C, Andrews PC, Feistner GJ, Scheller RH (1988) Isolation and characterization of a Drosophila neuropeptide gene. Neuron 1:55-61.

Norris BJ, Calabrese RL (1987) Identification of motor neurons that contain a FMRFamidc-likc peptide and the cffccts of FMRFamide on longitudinal muscle in the medicinal leech Hirudo medicinalis. $\mathrm{J}$ Comp Neurol 266:95-111.

Potter DD, Furshpan EJ, Landis SC (1983) Transmitter status in cultured rat sympathetic neurons: plasticity and multiple function. Fed Proc 42:1626-1632.

Price DA (1986) Evolution of a molluscan cardioregulatory neuropeptide. Am Zool 26:1007-1015.

Price DA, Greenberg MJ (1977) Structure of a molluscan cardioexcitatory peptide. Science 197:670-671.

Price DA, Greenberg MJ (1989) The hunting of the FaRPs: the distribution of FMRFamide-related peptides. Biol Bull 177:198-205.

Raffa RB (1988) The action of FMRFamide (Phe-Met-Arg-Phe- $\mathrm{NH}_{2}$ ) and related peptides on mammals. Peptides 9:915-922.

Sambrook J, Fritsch EF, Maniatis T (1989) Molccular cloning: a laboratory manual. Cold Spring Harbor, NY: Cold Spring Harbor Laboratory.

Sanger F, Nicklen S, Coulson AR (1977) DNA sequencing with chainterminating inhibitors. Proc Natl Acad Sci USA 74:5463-5467.

Saunders SE, Bright K, Kellet E, Benjamin PR, Burke JF (1991) Neuropeptides Gly-Asp-Pro-Phe-Leu-Arg-Phe-amide(GDPFLRFamide) and Ser-Asp-Pro-Phe-Leu-Arg-Phe-amide (SDPFLRFamide) are encoded by an exon $3^{\prime}$ to Phe-Met-Arg-Phe- $\mathrm{NH}_{2}$ (FMRFamide) in the snail Lymnaea stagnalis. J Neurosci 11:740-745.

Schacher S, Montarolo PG (1991) Target-dependent structural changes in sensory neurons of Aplysia accompany long-term heterosynaptic inhibition. Neuron 6:679-690.

Schaefer M, Picciotto MR, Kreiner T, Kaldany RR, Taussig R, Scheller RH (1985) Aplysia neurons express a gene encoding multiple FMRFamide neuropeptides. Cell 41:457-467.

Schinkmann K, Li C (1992) Localization of FMRFamide-like peptides in Caenorhabditis elegans. J Comp Neurol 316:251-260.

Schneider LE, Taghert PH (1988) Isolation and characterization of a Drosophilla gene that encodes multiple neuropeptides related to PheMet-Arg-Phe- $\mathrm{NH}_{2}$ (FMRFamide). Proc Natl Acad Sci USA 85:19931997.

Schneider LE, Taghert PH (1990) Organization and expression of the Drosophila Phe-Met-Arg-Phe- $\mathrm{NH}_{2}$ neuropeptide gene. J Biol Chem 265:6890-6895.

Spieth J, Denison K, Kirtland S, Cane J, Blumenthal T (1985) The C. elegans vitellogenin genes: short sequence repeats in the promoter regions and homology to vertebrate genes. Nucleic Acids Res 13: 5283-5295.

Taussig R, Scheller RH (1986) The Aplysia FMRFamide gene encodes sequences related to mammalian brain peptides. DNA 5:453-461.

Trimmer BA, Kobierski LA, Kravitz EA (1987) Purification and characterization of FMRFamidelike immunoreactive substances from the lobster nervous system: isolation and sequence analysis of two closely related peptides. J Comp Neurol 266:16-26.

Von Heijne G (1983) Patterns of amino acids near signal-sequence cleavage sites. Eur J Biochem 133:17-21.

Weiss KR, Bayley H, Lloyd PE, Tenenbaum R, Gawinowicz Kolks MA, Buck L, Cropper EC, Rosen SC, Kupfermann I (1989) Purification and sequencing of neuropeptides contained in neuron R15 of Aplysia californica. Proc Natl Acad Sci USA 86:2913-2917.

White JG, Southgate E, Thomson JN, Brenner S (1986) The structure of the nervous system of Caenorhabditis elegans. Philos Trans R Soc Lond [Biol] 314:1-340.

Wood BD (1988) The nematode Caenorhabditis elegans. Cold Spring Harbor, NY: Cold Spring Harbor Laboratory. 